\title{
Diversity of epiphytic lichens and their role in sequestration of atmospheric metals
}

\author{
S. Kar • A. C. Samal • \\ J. P. Maity $\cdot$ S. C. Santra
}

Received: 8 August 2012/Revised: 6 March 2013/Accepted: 16 March 2013/Published online: 17 April 2013

(C) Islamic Azad University (IAU) 2013

\begin{abstract}
Diversity and abundance of five species of epiphytic lichens were assessed in Kolkata, India. Significant correlation between abundance of lichen species and volume of vehicular traffic suggests atmospheric pollution load in urban region. Parmelia caperata (L.) Ach. and Graphis scripta (L.) Ach. exhibited higher abundance among the five species studied indicating their higher level of tolerance to air pollution. Significant correlations $(p<0.05)$ between levels of heavy traffic and both diversity and abundance of all lichen species were also observed. These findings indicate a potential threat to the survival of the lichen communities in Kolkata. Study further deals with quantifying the effectiveness of lichen species in accumulating metallic elements like $\mathrm{Pb}, \mathrm{Zn}$, and $\mathrm{Cu}$. This was achieved by analyzing the most abundant lichen species (Parmelia caperata) collected from nine different sites in winter, summer, and monsoon seasons. Metal content in lichen thalli, as analyzed by AAS, shows their elevated levels with the order $\mathrm{Pb}>\mathrm{Zn}>\mathrm{Cu}$. Relationship between metal content and volume of vehicular traffic suggests that co-associated, metallic elements are emitted as vehicle-derived pollutants as well as diffuse industrial emissions. Accumulation of these metals is
\end{abstract}

S. Kar · A. C. Samal · J. P. Maity - S. C. Santra

Department of Environmental Science, University of Kalyani,

Nadia 741235, West Bengal, India

S. Kar $(\bowtie)$

Department of Earth Sciences, National Cheng Kung University,

1, University Road, Tainan 70101, Taiwan

e-mail: sandeep@mail.ncku.edu.tw

J. P. Maity

Department of Earth and Environmental Sciences, National Chung Cheng University, Ming-Shung, 168 University Road, Chiayi County 62102, Taiwan higher in winter which is proportionate with the higher degree of metabolism due to higher humidity in this season. Study also demonstrates the dynamics of metal uptake by the lichen at different sites influenced with different degree of vehicular traffic. Overall results confirm suitability of lichen with their potential role in sequestration of atmospheric metal contamination.

Keywords Airborne metals - Bioaccumulation P Permelia caperata $\cdot$ Vehicular traffic

\section{Introduction}

Lichen has been recognized as a sensitive biological indicator of environmental condition specifically to air pollution (Bennett and Wetmore 1999; Bargagli et al. 2002; Blasco et al. 2011). Lichens show their sensitivity to air pollution in different ways such as decline in diversity, absence of sensitive species along with morphological, anatomical and physiological changes (Garty 1993; Bajpai et al. 2010a). The decline of lichens around urban region due to air pollution was well studied throughout the world (Loppi et al. 2004; Godinho et al. 2009). Lichen accumulates different gaseous pollutants and particulates containing metals and has been used as bioindicator in pollution monitoring. In polluted environments like cities, however, the nonselective accumulation by lichens continues and leads to sequestrate various pollutants including heavy metals. The majority of lichen species therefore cannot survive in polluted urban atmosphere due to toxicological effects of those pollutants (especially gaseous elements like $\mathrm{SO}_{2}$ and NOx) if accumulated in a greater amount. This leads to dramatic loss of the epiphytic lichen flora in cities around the world (Adamo et al. 2008; Bajpai et al. 2010a). 
Brawn and Odgen (1976) established a relationship between lichens diversity and abundance with the traffic volume in Halifax city (Nova Scotia, Canada), as the automobile exhaust is considered to be the principal source of atmospheric pollution in urban environment. Since then extensive work has been undertaken during the past three decades to study the biomonitoring of airborne contaminants using lichens (Bennett and Wetmore 1999; Uijily and Kumaraguru 2004; Scheidegger and Werth 2009).

Absorption and accumulation of metals by lichens from the contaminated atmosphere were reported worldwide (Clair et al. 2002; Adamo et al. 2008; Bajpai et al. 2010b, 2011). Therefore, lichens have been used to monitor atmospheric depositions of a large number of metals and act as an air filter particularly in urban environment. Metal uptake ability of lichens and its significant correlation with atmospheric metal level has led to their wide-scale application as practical biomonitors of atmospheric contamination (Godinho et al. 2009). Several lichen species are capable of accumulating airborne metals like $\mathrm{Cu}, \mathrm{Zn}, \mathrm{Pb}$, $\mathrm{Ni}$, and $\mathrm{Cd}$ within the intercellular space of the thallus (Rizzio et al. 2001; Bajpai et al. 2011; Bajpai and Upreti 2012). Lichens accumulate metals in their thalli either on the outer surface of the walls of the fungal hyphae or within the walls themselves (Bajpai et al. 2010a). But some of the metals thus absorbed by the lichen thalli gain entry into the cells and ultimately take part in the metabolism. Finally, they may lead to the death due to toxicity of higher content of those metals accumulated (Dzubaj et al. 2008). Levels of atmospheric $\mathrm{Cd}, \mathrm{Cr}, \mathrm{Cu}, \mathrm{Hg}, \mathrm{Ni}, \mathrm{Pb}$, and $\mathrm{Zn}$ around Pistoia in Central Northern Italy were assessed using the widely distributed indigenous lichen Parmelia caperata (Loppi et al. 1997). Metal contents in lichen thalli have been shown to correlate with atmospheric metal levels, where decrease of metal concentrations in lichen species was found to be correlated with increase in distance from the source (Cristofolini et al. 2008). Therefore, lichen biomonitoring is an interesting tool for environmental assessment with plenty of applications in the evaluation of most notorious airborne contaminants, including metals.

In India, the perceptible decline in the vegetation cover, the loss of species-specific habitats over the years, the increase in industrial areas and growth of large urban areas are some of the leading factors resulting in the loss and change of diversity of lichens (Upreti 1996; Bajpai et al. 2010a). Another factor with a potential influence in the natural distribution of the lichen species are microclimatic change. Apart from the abiotic factors, structure of bark, bark-wounds and water-holding capacity of bark also influence the diversity of epiphytic lichens. There are several studies on status of lichen diversity in Kolkata city which have scares growth of lichen species (Das et al. 1986; Upreti et al. 2005). In earlier study, 25 lichen species were identified among different localities of the city with most of them found in peripheral area (Upreti et al. 2005) and $P$. caperata was reported as pollution-tolerent species found on the street trees (Das et al. 1986; Majumder et al. 2012). The present study is concerned, with the distribution and abundance of epiphytic lichens and their relation to varying levels of traffic. The objective was to establish whether traffic volume within the city affects the distribution, diversity and abundance of the lichen thalli, with special reference to metal bioaccumulation capacity. The study also focuses on the dynamics of the metal accumulation, thereby aiming to increase the possibilities of sequestration of metallic elements deposited in atmosphere. This study was conducted in Kolkata city (West Bengal, India) in the period of April 2005 to January 2006.

\section{Materials and methods}

\section{Study area}

Kolkata city is located $\left(22^{\circ} 25^{\prime} \mathrm{N}\right.$ to $22^{\circ} 40^{\prime} \mathrm{N}$ and $88^{\circ} 20^{\prime}$ $\mathrm{E}$ to $88^{\circ} 35^{\prime} \mathrm{E}$ ) on the deltaic plateau of lower Gangetic basin, West Bengal, India (Fig. 1). The surrounding area is a flat swampy region with a subtropical climate. Average temperature and humidity of this region is $27^{\circ} \mathrm{C}$ and $67 \%$, respectively, with moderate rainfall of maximum $320 \mathrm{~mm}$ during monsoon (Fig. 2). Kolkata is one of the largest metropolis and fastest growing cities in India. Increased urbanization, industrialization and heavy vehicular traffic have resulted in deterioration of air quality in the city. The major contributor of atmospheric contaminants particularly trace elements is mainly vehicular and diffuse industrial emission (Kar et al. 2010). In earlier study on atmospheric particulate pollution, it is reported that the amounts of particulate levels are much higher in Kolkata city (Mean SPM $362 \mu \mathrm{g} / \mathrm{m}^{3}$ ) compared to unpolluted villages (Suburban of Kalyani township, Mean SPM $176 \mu \mathrm{g} / \mathrm{m}^{3}$ ) (Kar et al. 2010). Study also showed the metallic elements $(\mathrm{Zn}, \mathrm{Cu}, \mathrm{Ni}, \mathrm{Pb}, \mathrm{Co}, \mathrm{Fe}$, and $\mathrm{Mn})$ are significantly higher in aerosols of Kolkata city as well compared to unpolluted villages (Karar et al. 2006; Kar et al. 2010). These previous findings insisted to concentrate on polluted site to assess the biofiltration ability of those airborne metals by lichens.

\section{Sample collection}

Nine sampling sites (marked in Fig. 1) were selected on the major arterial roads of Kolkata city for the study of lichen diversity and abundance. At each sampling site ten trees (of $60-120 \mathrm{~cm}$ diameter) were selected based on availability of lichens on these tree barks. These trees are Mangifera 
Fig. 1 Study area of Kolkata Metropolis, situated in the fringes of river Ganges. Nine sampling sites, marked in circle, were selected along east-west and north-south traverse area of the city and on the major arterial roads with plantation cover

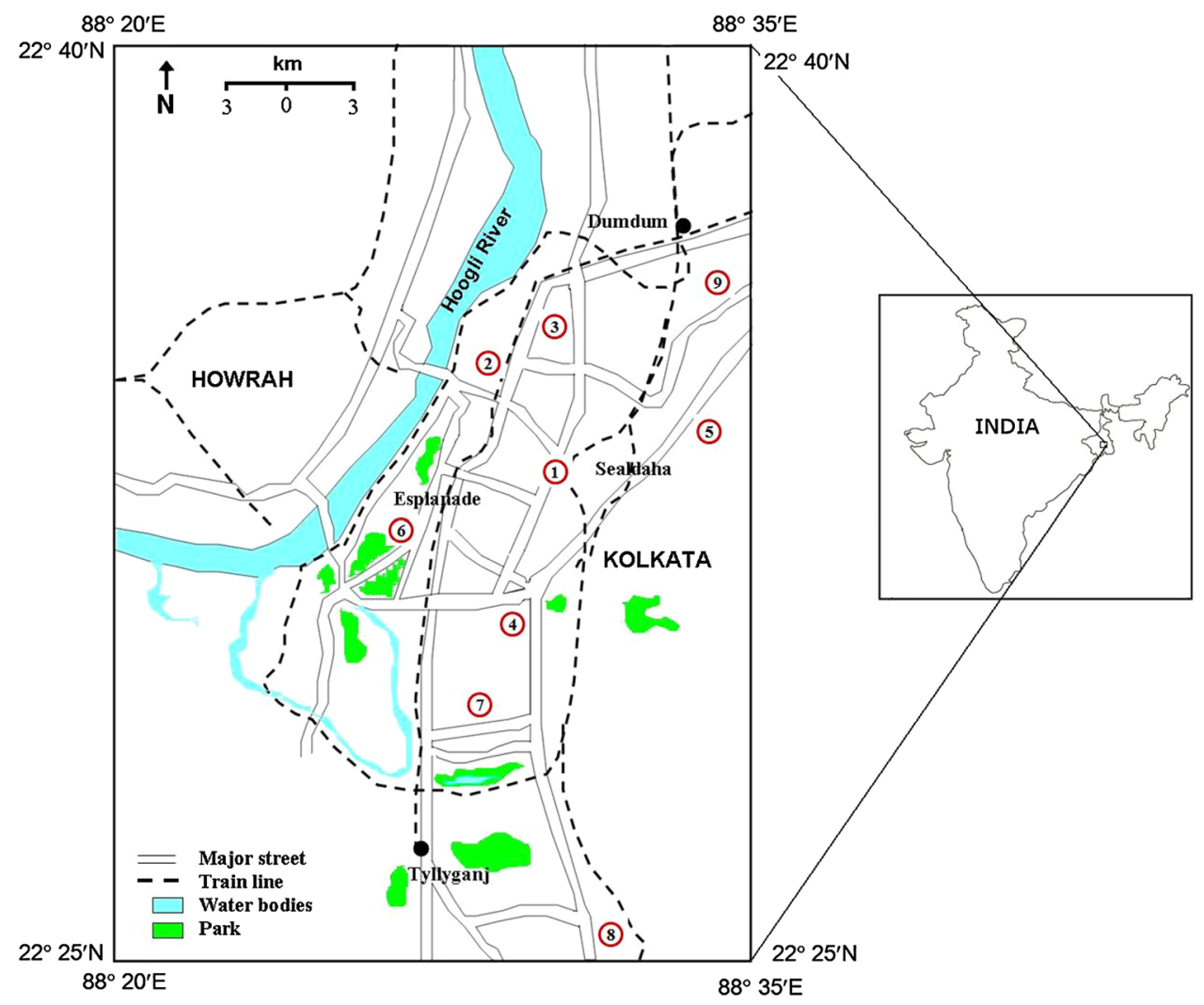

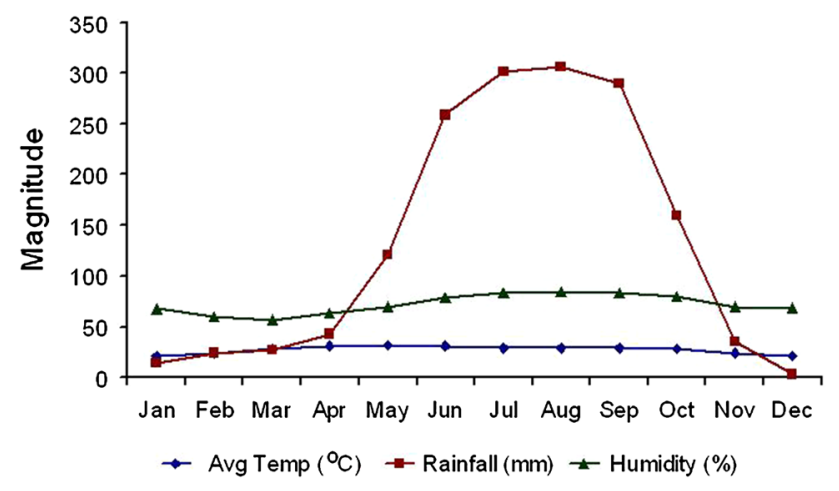

Fig. 2 Variation of temperature, humidity, and rainfall throughout the year 2005 in study area. Magnitude of each parameter represents their average value (source: Alipore Meteorological Department)

indica, Alstonia scholaris, Albizia lebbeck, Polyalthia longifolia, Putranjiva roxburghii, and Anthocephalus chinensis. Abundance of lichens was determined using the combined cover-abundance scale of Braun-Blanquet (Phillips 1959) (Table 1). The number and abundance of each lichen species growing on the tree trunk at $0.5-2 \mathrm{~m}$ from the ground were estimated. Thalli of different lichen species were collected randomly from five to ten trees in each sampling site within $100 \mathrm{~m}$ in the year 2005-2006. In each sampling site, three specimen of each lichen species were collected for identification. Thalli of each species were carefully separated from tree bark and cleaned with thin brush to remove dust, fungi and other extraneous materials without washing (Conti et al. 2004). Five lichen species were identified through morphological and anatomical study with the help of a microscope using identification keys (Awasthi 1988, 1991). Only foliose lichen $P$. caperata was chosen for metal content analysis as it has large surface area for possible higher metal accumulation and thallus can be easily detached from tree bark. It was also the most abundant species found in the study area. Total of 36 samples of $P$. caperata, four samples from each site with a mass ranging between 5 and $10 \mathrm{~g}$ were collected separately in three seasons i.e., summer (April-May), monsoon (July-August) and winter (December-January). Sample collections were performed using Teflon-coated scalpels to avoid any metal contamination and after sampling lichen thalli were kept in polypropylene packets for further treatment in the laboratory.

\section{Metal analysis}

After cleaning, thalli of $P$. caperata were separated from their substratum and mixed together for homogeneity. Next they were dried in an oven (at $60{ }^{\circ} \mathrm{C}$ ) for $24 \mathrm{~h}$. The dried samples were then powdered using a ceramic pestle and mortar. $0.5 \mathrm{~g}$ of dried powder samples were placed in a Teflon bomb and mixed with $2 \mathrm{~mL}$ of concentrated $\mathrm{HNO}_{3}$ (E. Merck, India) and $1 \mathrm{ml}$ of $\mathrm{HClO}_{3}(60 \% \mathrm{~V} / \mathrm{V}, \mathrm{E}$. Merk, 
Table 1 Abundance of five lichen species in different study sites of Kolkata metropolis along with traffic volume

\begin{tabular}{|c|c|c|c|c|c|c|c|}
\hline \multirow[t]{2}{*}{ Study sites } & \multirow{2}{*}{$\begin{array}{l}\text { Traffic volume } \\
\text { (vehicles/h) }\end{array}$} & \multirow{2}{*}{$\begin{array}{l}\text { Number of heavy } \\
\text { traffic (bus/h) }\end{array}$} & \multicolumn{5}{|c|}{ Lichen species } \\
\hline & & & $\begin{array}{l}\text { Parmelia } \\
\text { caperata }\end{array}$ & $\begin{array}{l}\text { Graphis } \\
\text { scripta }\end{array}$ & $\begin{array}{l}\text { Bacidea } \\
\text { convexula }\end{array}$ & $\begin{array}{l}\text { Pyrenula } \\
\text { nitida }\end{array}$ & $\begin{array}{l}\text { Trypthelium } \\
\text { tropicum }\end{array}$ \\
\hline $\begin{array}{l}\text { A.J.C. Bose } \\
\text { Road (1) }\end{array}$ & 5,280 & 1,220 & + & - & - & - & - \\
\hline $\begin{array}{l}\text { Mallic Bazar } \\
\text { (2) }\end{array}$ & 3,680 & 840 & 1 & - & - & - & - \\
\hline Girish Park (3) & 2,520 & 660 & 2 & 1 & - & - & - \\
\hline Park Circus (4) & 2,440 & 540 & 1 & - & - & - & - \\
\hline $\begin{array}{l}\text { Eastern Bye } \\
\text { Pass (5) }\end{array}$ & 2,060 & 240 & 2 & 1 & + & - & - \\
\hline Maidan (6) & 2,000 & 270 & 2 & 2 & 1 & - & + \\
\hline $\begin{array}{l}\text { Southern } \\
\text { Avenue (7) }\end{array}$ & 1,840 & 340 & 3 & 1 & 1 & + & - \\
\hline $\begin{array}{l}\text { Narendrapur } \\
\text { (8) }\end{array}$ & 1,720 & 220 & 3 & 3 & 1 & 1 & + \\
\hline Baguihati (9) & 1,260 & 320 & 2 & 2 & 1 & + & - \\
\hline
\end{tabular}

Combined cover/abundance scale: (Phillips 1959)

+ sparsely or very sparsely present, cover very small, 1 plentiful but of small cover value, 2 very numerous or covering at least $0.05 \%$ of area, 3 any number of individuals covering 0.25 to $0.5 \%$ of area, 4 any number of individuals covering 0.5 to $0.75 \%$ of area, 5 covering more than $0.75 \%$ of area

India). The solution was then allowed to stand for few minutes at room temperature and agitated to avoid bubbling and finally kept overnight. The next day the bomb was placed in a hot air oven (at $120^{\circ} \mathrm{C}$ ) for $8 \mathrm{~h}$. After cooling, the solution was collected from the Teflon bomb with repeated washing using deionized water. The sample volume was reduced to about $0.5-1 \mathrm{~mL}$ using a hot plate at a temperature $60-80{ }^{\circ} \mathrm{C}$. After cooling the volume of the solution was made up to $2 \mathrm{~mL}$ with deionized water and filtered through a Millipore membrane $(0.45 \mu \mathrm{m}$ pore size $)$ to prepare it for total metal analysis.

Three heavy metals $(\mathrm{Pb}, \mathrm{Cu}$, and $\mathrm{Zn}$ ) were chosen for metal analysis of lichen thalli due to their dominance in atmospheric aerosols (Karar et al. 2006). Analysis of these metals was undertaken by a spectrophotometric technique using Atomic Absorption Spectrometer (AA400, PerkinElmer, NL). For quality control and quality assurance, standard reference materials (NIST, SRM 1570a) were analyzed and the experimental values show good agreement (accuracy: $\pm 6 \%$ and precision: $\pm 5 \%$ ) with the certified values. Spearman correlation test has been performed to assess the relationship between different variables like traffic volume, levels of traffic and lichen diversity. We also examined the lichen diversity, traffic volumes and association with metal accumulation using one-way ANOVA to test hypothesis about differences between multiple mean values. $F$ value and $\mathrm{CV}$ were calculated to assess the variability of accumulation of metals in lichen species among different sampling sites. The level of significance was considered at $p<0.05$.

\section{Results and discussion}

Abundance and diversity of epiphytic lichens

The present study revealed that five species of epiphytic lichens were found in Kolkata city at nine different sampling sites. These species were Parmelia caperata (L.) Ach. and Graphis scripta (L.) Ach., Bacidia convexula (Müll. Arg.) Zahlbr., Pyrenula nitida (Weigel) Ach. and Trypthelium tropicum (Ach.) Müll. Arg. Diversity of lichens, their abundance with respect to levels of vehicular traffic was presented in Table 1. P. caperata was the most abundant species found at all the sampling sites in Kolkata city while another species G. scripta was found at $66 \%$ of the sites (Fig. 3). P. caperata can be considered as the most resistant epiphytic lichen (Majumdar et al. 2009; Majumder et al. 2012) whereas G. scripta as low resistant. Among the five lichen species found, crustose type lichens were diversive with four species and $P$. caperata was found only as foliose type. The observed lichen diversity was significantly correlated $(R=0.65, p<0.05)$ with traffic volume and traffic status (Fig. 4). High traffic zone consisting 2,000 or more vehicular traffic showed less diversity and abundance of lichens while low traffic zone $(<2,000)$ 

of five epiphytic lichens observed in nine sampling sites of study area. Abundance of each lichen species is represented (Bar diagram) by their rank of coverage as described in Table 1. Line diagram shows the variation of total traffic volume (per hour) among the nine sampling sites. Sampling sites are ranked based on total traffic volume (per hour)
Fig. 3 Diversity and abundance
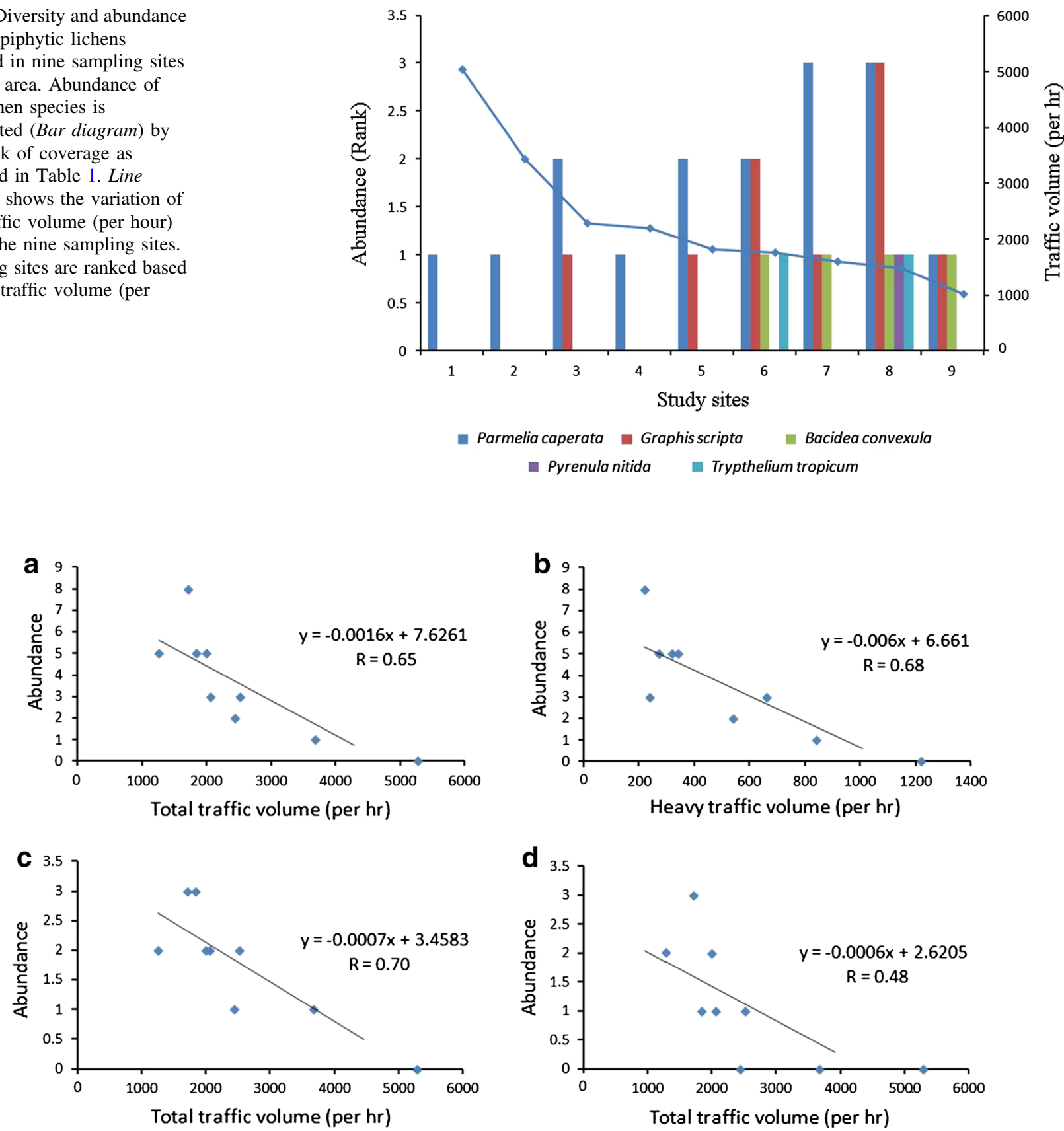

Fig. 4 Relationship between a combined abundance of five lichen species and total traffic volume (per hour), $\mathbf{b}$ combined abundance of five lichen species and total heavy traffic (bus/hour), c abundance of $P$. caperata and total traffic volume (per hour), $\mathbf{d}$ abundance of

showed higher diversity and abundance (Brawn and Odgen 1976). The coverage of tree trunks by lichens in E M bye pass was much larger than other sites in the city, indicating better air quality along the eastern part of the city. Number of heavy traffic (bus) also found to be responsible for lichen diversity and abundance as revealed in the study

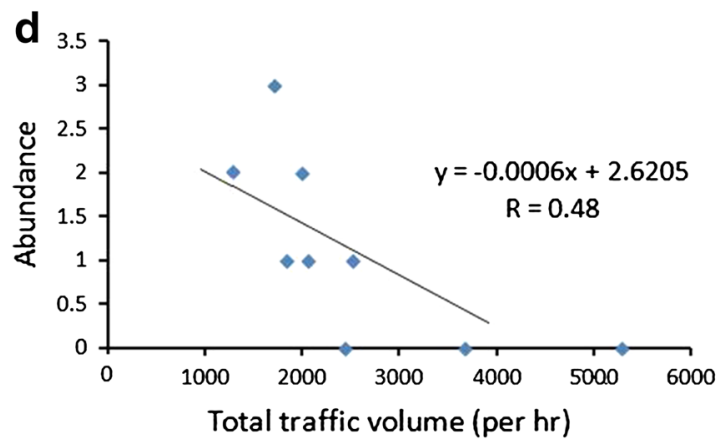

G. scripta and total traffic volume (per hour). Abundance of lichen species is represented by their rank of coverage as described in Table 1

(Fig. 4). This was mainly due to atmospheric pollution generated by anthropogenic emissions from automobiles and diffuse industrial activities (Majumdar et al. 2009). Therefore, atmospheric contamination specifically vehicular emission was found to be greatly responsible for this type of lichen diversity and abundance in the study area. 
Table 2 Spearman rank correlation coefficient and test of null hypothesis of number of association $(n=9)$

\begin{tabular}{lll}
\hline Correlation tested & $R$ & Conclusion at 0.05 level of significance \\
\hline Total traffic volume vs diversity (all species) & 0.65 & Signification correlation \\
Level of heavy traffic vs diversity (all species) & 0.686 & Signification correlation \\
Total traffic volume vs abundance of Parmelia caperata & 0.707 & Signification correlation \\
Total traffic volume vs abundance Graphis scripta & 0.484 & Less signification correlation \\
\hline
\end{tabular}

Table 3 Trace metal content $(\mathrm{Pb}, \mathrm{Zn}$, and $\mathrm{Cu})$ of Parmelia caperata in different study sites according to general traffic rank and results of ANOVA

\begin{tabular}{|c|c|c|c|c|}
\hline \multirow[t]{2}{*}{ General traffic rank } & \multirow[t]{2}{*}{ Seasons } & \multicolumn{3}{|c|}{ Metal content $(\mu \mathrm{g} / \mathrm{g})(n=4)$} \\
\hline & & $\mathrm{Pb}$ & $\mathrm{Zn}$ & $\mathrm{Cu}$ \\
\hline \multirow[t]{3}{*}{1} & Winter & $314 \pm 14.5$ & $50.4 \pm 3.22$ & $25.7 \pm 0.74$ \\
\hline & Summer & $280 \pm 12.4$ & $40.2 \pm 1.67$ & $15.4 \pm 0.36$ \\
\hline & Monsoon & $267 \pm 10.6$ & $19.4 \pm 1.84$ & $5.92 \pm 0.43$ \\
\hline \multirow[t]{3}{*}{2} & Winter & $300 \pm 15.3$ & $54.6 \pm 3.85$ & $29.3 \pm 0.47$ \\
\hline & Summer & $275 \pm 15.9$ & $39.7 \pm 1.78$ & $18.2 \pm 0.58$ \\
\hline & Monsoon & $280 \pm 11.7$ & $30.4 \pm 2.83$ & $16.5 \pm 0.35$ \\
\hline \multirow[t]{3}{*}{3} & Winter & $249 \pm 13.2$ & $34.6 \pm 1.85$ & $39.4 \pm 1.38$ \\
\hline & Summer & $232 \pm 11.8$ & $24.6 \pm 1.16$ & $21.8 \pm 1.17$ \\
\hline & Monsoon & $220 \pm 13.8$ & $14.2 \pm 0.82$ & $6.63 \pm 0.48$ \\
\hline \multirow[t]{3}{*}{4} & Winter & $77.6 \pm 5.61$ & $34.8 \pm 2.75$ & $18.2 \pm 0.76$ \\
\hline & Summer & $69.3 \pm 4.75$ & $40.2 \pm 2.57$ & $15.6 \pm 0.78$ \\
\hline & Monsoon & $55.8 \pm 2.93$ & $30.7 \pm 1.24$ & $8.75 \pm 0.63$ \\
\hline \multirow[t]{3}{*}{5} & Winter & $170 \pm 6.36$ & $29.8 \pm 1.89$ & $11.3 \pm 0.56$ \\
\hline & Summer & $165 \pm 9.73$ & $28.5 \pm 0.95$ & $13.4 \pm 0.77$ \\
\hline & Monsoon & $150 \pm 3.74$ & $30.6 \pm 1.46$ & $6.28 \pm 0.22$ \\
\hline \multirow[t]{3}{*}{6} & Winter & $75.6 \pm 4.83$ & $32.6 \pm 1.93$ & $30.8 \pm 1.18$ \\
\hline & Summer & $70.2 \pm 2.88$ & $53.7 \pm 1.43$ & $12.6 \pm 0.85$ \\
\hline & Monsoon & $52.7 \pm 6.75$ & $20.4 \pm 0.97$ & $18.1 \pm 27$ \\
\hline \multirow[t]{3}{*}{7} & Winter & $120 \pm 3.72$ & $34.7 \pm 0.81$ & $22.6 \pm 0.72$ \\
\hline & Summer & $104 \pm 6.97$ & $23.4 \pm 0.75$ & $5.46 \pm 0.25$ \\
\hline & Monsoon & $110 \pm 6.74$ & $19.1 \pm 1.36$ & $15.9 \pm 0.61$ \\
\hline \multirow[t]{3}{*}{8} & Winter & $70.5 \pm 6.19$ & $19.7 \pm 1.26$ & $19.2 \pm 0.57$ \\
\hline & Summer & $66.7 \pm 4.26$ & $10.9 \pm 0.78$ & $15.7 \pm 0.56$ \\
\hline & Monsoon & $20.2 \pm 1.87$ & $5.42 \pm 0.24$ & $9.08 \pm 0.43$ \\
\hline \multirow[t]{6}{*}{9} & Winter & $70.8 \pm 5.26$ & $30.7 \pm 1.45$ & $11.8 \pm 0.87$ \\
\hline & Summer & $65.5 \pm 3.59$ & $26.4 \pm 1.38$ & $7.04 \pm 0.45$ \\
\hline & Monsoon & $60.9 \pm 3.34$ & $20.8 \pm 1.13$ & $6.28 \pm 0.28$ \\
\hline & $F$ value & 14.5 & 9.12 & 21.7 \\
\hline & $p$ value & 0.002 & 0.008 & 0.03 \\
\hline & $\mathrm{CV}$ & 0.14 & 0.17 & 0.11 \\
\hline
\end{tabular}

Impact of urban traffic on diversity of epiphytic lichens

In the present study, highest traffic volume was ranked 1 showing lowest score of abundance, while lower traffic volume was related to higher species diversity and abundance. The Spearman rank correlation coefficient of association between two variables in ordered series is calculated (Table 2). The test of correlation coefficient indicates an association between traffic volume and diversity of lichens especially with $P$. caperata $(R=0.70$, $p<0.05)$ and $G$. scripta $(R=0.48, p<0.05)$. However, there is also a significant correlation $(R=0.68, p<0.05)$ 

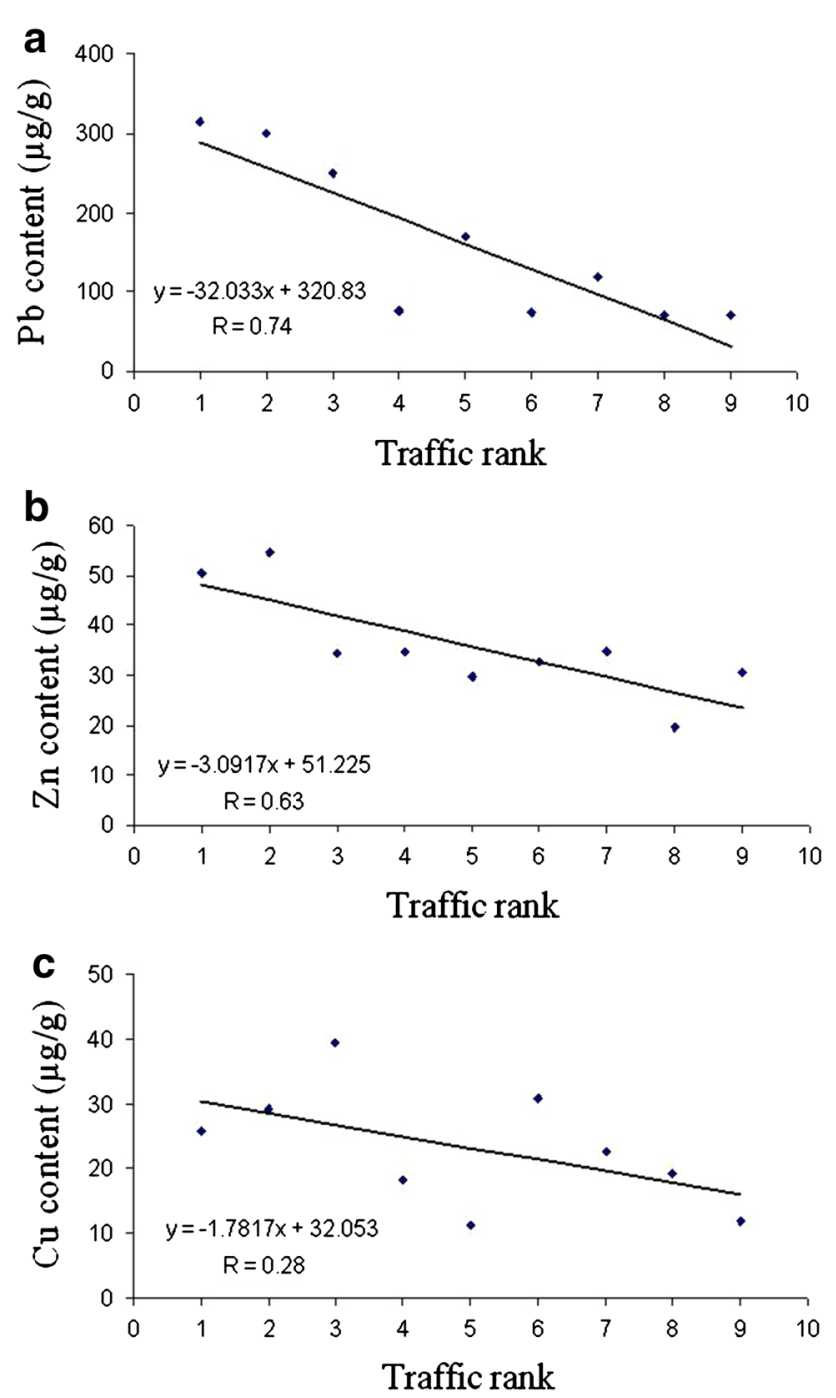

Fig. 5 Relationship between metal contents (winter accumulation) in $P$. caperata and general traffic rank $\mathbf{a} \mathrm{Pb}, \mathbf{b} \mathrm{Zn}$, and $\mathbf{c} \mathrm{Cu}$

between levels of heavy vehicle (bus) and lichen diversity. Therefore within the city, the number of vehicles daily passing by a sampling station has an apparent effect on lichen diversity and abundance. In another way, the more buses that pass by a station, the fewer the numbers of species and of individuals.

It is well known that the environmental factors other than air pollution also affect the distribution of lichens (Hauck 2011). Importance of climatic setting is also a key driver of the diversity and abundance of epiphytic lichen community (Ellis and Coppins 2010). Though climatic gradient of entire study area is considered same (Fig. 2), still it has significant influence on the lichen composition and extent of accumulation of airborne contaminants. Thus, at a regional scale climatic setting and pollution regime are both act as a key factor for lichen abundance. However, in the present study, the position of the trees in relation to road/street, the position of the lichens on the tree, and the age of the trees were kept relevantly constant. Thus, observed relationship between traffic volume and species diversity under these circumstances suggests that traffic volume in general has a great effect on lichen distribution in the city.

Metal content in lichen and its implication on atmospheric contamination

Content of metals $(\mathrm{Pb}, \mathrm{Zn}$, and $\mathrm{Cu})$ in $P$. caperata in three different seasons and their ANOVA results were presented in Table 3. Among the three metals, accumulation of $\mathrm{Pb}$ in lichen thallus was higher compared to $\mathrm{Zn}$ and $\mathrm{Cu}$ with the ranking of $\mathrm{Pb}>\mathrm{Zn}>\mathrm{Cu}$. Identically, metal accumulation was found maximum in winter, and minimum in monsoon season. Data shows maximum metal accumulation occurred at A.J.C. Bose Road with high traffic load. Similarly, accumulation of metals in Baguihati road shows minimum with low traffic load. Positive correlation between metal content of lichen thalli and traffic rank was observed in case of $\mathrm{Pb}(R=0.74, p<0.05)$ and $\mathrm{Zn}(R=0.63$, $p<0.05$ ) (Fig. 5). However, $\mathrm{Cu}$ content in lichen does not show any such relationship with traffic ranking. Coefficient of variation is higher in case of $\mathrm{Zn}(0.17)$ compared to $\mathrm{Pb}$ (0.14) and $\mathrm{Cu}(0.11)$. Lower $\mathrm{CV}$ of $\mathrm{Cu}$ and $\mathrm{Pb}$ suggests greater dispersion of metal-associated particles and their subsequent trapping by lichens (Garty 2001).

Present study highlights the metal uptake by $P$. caperata and capture efficiencies of them in urban Kolkata. The metal capture by lichens occurs mostly in winter period as evidenced from the Table 3. Higher uptake of $\mathrm{Pb}$ by $P$. caperata reflects its greater presence in atmospheric particulates relative to $\mathrm{Zn}$ and $\mathrm{Cu}$ (Cloquet et al. 2006; Paoli et al. 2011). Though $\mathrm{Pb}$ content is substantially reduced in aerosols in recent days due to ban of leaded fuel for several years (Kar et al. 2010), still its presence indicates its availability in urban aerosols from anthropogenic sources. Considerably high amount of $\mathrm{Pb}$ was possibly due to vehicular emission and other industrial activities in and around the city (Russellflegal et al. 2010; Kar et al. 2010, 2013). $\mathrm{Pb}$ was found to be efficiently accumulated by lichens from aerosols and metal fall out as reported earlier (Cloquet et al. 2006; Bajpai et al. 2010b). However, relatively heavy traffic conditions by automobiles could have been the primary cause for the $\mathrm{Pb}$ accumulation. $\mathrm{Cu}$ content in lichen was seems to be within the background level though its variation among different sites suggests diesel engines and unleaded gasoline as possible sources (Majumder et al. 2012). The level of $\mathrm{Zn}$ is considered to be higher in such high traffic urban region with possible sources of abrasion of motor vehicle tyres (Garty 2001). However, the usage of these metals in electroplating, 

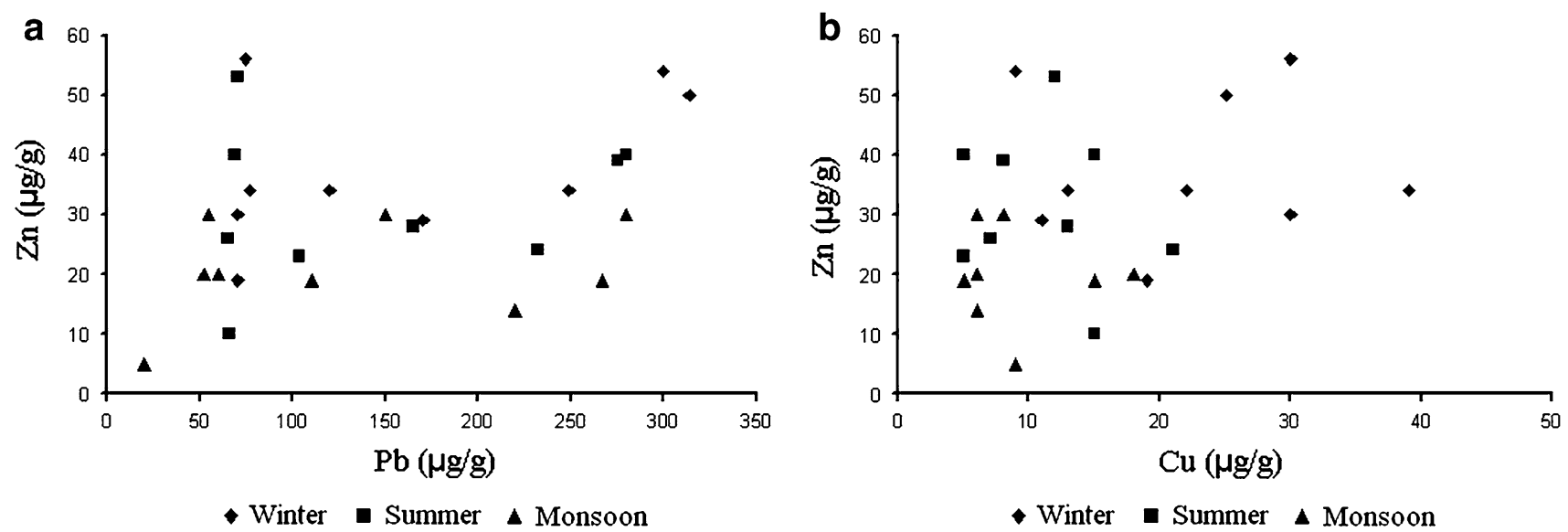

Fig. 6 Relationship between a $\mathrm{Pb}$ and $\mathrm{Zn}, \mathbf{b} \mathrm{Zn}$ and $\mathrm{Cu}$ content in $\mathrm{P}$. caperata in three seasons (winter, summer and monsoon)

pesticides, fossil fuel combustion in restaurants and residences could have the other source for their availability in atmosphere (Kar et al. 2010, 2013). Irrespective of abundance of these metallic elements in this urban environment, no such significant relationship was observed between $\mathrm{Pb}, \mathrm{Cu}$, and $\mathrm{Zn}$ indicating their emission from diffused anthropogenic sources (Fig. 6).

Lichen like $P$. caperata with rough surfaces and special morphological character is considered to be more efficient in intercepting particulate matter as well as metallic elements (Garty 2001; Koz et al. 2010). The ability of capturing particulates as well as metals by other group of lichens has been reported elsewhere (Simonetti et al. 2003; Bajpai et al. 2010a). The assessment of metal uptake by lichens across an urban region provides an opportunity to consider the source factors which determine capture efficiency and particulate accumulation. This was evident from the fact that $P$. caperata collected from different sites showed varied quantities of metal accumulation with significant differences $(p<0.05)$ between all sites. The urban environment of Kolkata city is therefore exposed to atmospheric particulate pollution containing heavy metals due to different anthropogenic activities. Therefore, greater accumulation of metals in the lichens was indicative of the possibly greater level of atmospheric pollution load in Kolkata. The specific ability of absorbing and accumulating this type of pollutants from the air, their longevity and resistance to the environmental stresses, make lichens suitable for studies on air quality assessment of airborne contaminants and their sequestration.

Bioaccumulation of metals and their sequestration by lichen community

It is interesting that $P$. caperata selected as most abundant lichen species in study area contains elevated levels of metallic elements in their thallus. Therefore, this lichen species can be regarded as sensitive to metal contamination and has been recommended as a particularly suitable bioindicator of heavy metal burden (Backor and Vaczi 2002; Baptista et al. 2008). Lichens may govern the extent of uptake of metals and the stronger metal accumulators possessed most abundant lichens which gave rise to the effective trapping and filtering the contaminants from atmosphere (Minganti et al. 2003). Considering the metal content of $P$. caperata, the findings indicate a potential influence of bioaccumulative capabilities of this particular species in Kolkata city (Majumder et al. 2012). Moreover, the degree of metal uptake by lichens is affected by combined interactive factors which include anthropogenic origin; efficiency of particulate adsorption, a real coverage of lichens; intensity of precipitation; and degree of traffic disturbance (Garty 2001). Analysis of indigenous lichen species like $P$. caperata in Kolkata city demonstrated spatial and temporal changes in airborne heavy metal levels and their distribution in the study area. Being the most abundant lichen species, $P$. caperata likely favors the polluted atmosphere of Kolkata city.

Atmospheric contamination is an important mechanism which controls the fate of toxic airborne pollutants especially metallic elements and their transfer from the atmosphere to the natural organisms like lichens (Paoli et al. 2011; Kar et al. 2013). Among the contamination processes, emission from source is significant which comprises transport of pollutants either from diffuse or point source and getting dispersed to the surrounding area and finally uptake by natural surface like tree canopy (Kumar et al. 1991; Kar et al. 2006, 2013). This study indicates that the surface of living organism provide a filtration and reaction surface to the atmosphere and also important function to transfer pollutants from the atmosphere to the biosphere. The specific ability of uptake of this metals from the air, their stability and resistance to the environmental stresses, make this lichen species suitable for 
biomonitoring studies (Hauck 2011). Therefore, biomonitoring of trace metals is an interesting tool for environmental assessment with plenty of applications in the evaluation of most notorious air borne contaminants, including toxic metals. It is clear that available species and location relative to pollution source are critical in determining the effectiveness of metal capture by lichens (Paoli et al. 2011). This study has shown that in the urban environment, lichen is a suitable passive bioaccumulator, useful to assess levels and distribution patterns of inorganic particulates. Finally, the data have implications for the control of sources where protection of people from exposure to metallic particulates might be achieved.

\section{Conclusion}

Investigation on diversity and abundance of epiphytic lichens in Kolkata city showed reducing trend due to influence of increased vehicular traffic. Significant correlation was observed between general traffic volume and diversity of five lichen species. The use of epiphytic lichen (P. caperata) as bioindicator of the degree of atmospheric pollution with respect to metallic elements is highlighted in the present study. Lichen thalli exhibit significant enhancement of metallic elements with $\mathrm{Zn}, \mathrm{Pb}$, and $\mathrm{Cu}$, reflecting surface uptake from atmosphere. The winter accumulation of these metals is higher due to higher abundance of atmospheric particulates. Metal-rich particulate sources are basically anthropogenic input from diffuse vehicular and industrial emission. Their magnitude was seemed to depend strongly as a function of the atmospheric availability of these metallic elements especially $\mathrm{Pb}$. Present study therefore provides the extent of the atmospheric particulate load and possible threat to diversity and abundance of epiphytic lichens in urban Kolkata.

Acknowledgments Authors would like to thank Department of Environmental Science, University of Kalyani for providing research and experimental facilities.

\section{References}

Adamo P, Bargagli R, Giordano S, Modenesi P, Monaci F, Pittao E, Spagnuolo V, Tretiach M (2008) Natural and pre-treatments induced variability in the chemical composition and morphology of lichens and mosses selected for active monitoring of airborne elements. Environ Pollut 152:11-19

Awasthi DD (1988) A key to the macro lichens of India and Nepal. J Hattori Bot Lab 65:207-302

Awasthi DD (1991) A key to the microlichens of India, Nepal and Sri Lanka. J Cramer, Berlin \& Stuttgart

Backor M, Vaczi P (2002) Copper tolerance in the lichen photobiont Trebouxia erici (Chlorophyta). Environ Exp Bot 48:11-20
Bajpai R, Upreti DK (2012) Accumulation and toxic effect of arsenic and other heavy metals in contaminated area of WestBengal, India, in the lichen Pyxine cocoes (Sw.) Nyl. Ecotoxicol Environ Safety 83:63-70

Bajpai R, Upreti DK, Nayaka S, Kumari B (2010a) Biodiversity, bioaccumulation and physiological changes in lichens growing in the vicinity of coal-based thermal power plant of Raebareli district, north India. J Hazard Mater 174:429-436

Bajpai R, Upreti DK, Dwivedi SK (2010b) Passive monitoring of atmospheric heavy metals in a historical city of central India by Lepraria lobificans Nyl. Environ Monit Assess 66:477-484

Bajpai R, Mishra GK, Mohabe S, Upreti DK, Nayaka S (2011) Determination of atmospheric heavy metals using two lichen species in Katni and Rewa cities, India. J Environ Biol 32:195-199

Baptista MS, Teresa M, Vasconcelos SD, Cabral JP, Freitas MC, Pacheco AMG (2008) Copper, nickel and lead in lichen and tree bark transplants over different periods of time. Environ Pollut 151:408-413

Bargagli R, Monaci F, Borghini F, Bravi F, Agnorelli C (2002) Mosses and lichens as biomonitors of trace metals. A comparison study on Hypnum cupressiforme and Parmelia caperata in a former mining district in Italy. Environ Pollut 116:279-287

Bennett JP, Wetmore CM (1999) Changes in element contents of selected lichens over 11 years in northern Minnesota, USA. Environ Exp Bot 41:75-82

Blasco M, Domeno C, Lopez P, Nerin C (2011) Behaviour of different lichen species as biomonitors of air pollution by PAHs in natural ecosystems. J Environ Monit 13:2588

Brawn K, Odgen JG (1976) Lichen diversity and abundance as affected by traffic volume in an urban environment. Urban Ecol 2:235-244

Clair SB, Clair LL, Mangelson NF, Weber DJ (2002) Influence of growth form on the accumulation of airborne copper by lichens. Atmosph Environ 36:5637-5644

Cloquet C, Carigan J, Libourel G (2006) Isotopic composition of $\mathrm{Zn}$ and $\mathrm{Pb}$ atmospheric depositions in an urban/periurban area of northeastern France. Environ Sci Technol 40:6594-6600

Conti ME, Tudino MB, Stripeikis J, Cecchetti G (2004) Heavy metal accumulation in the lichen Evernia Prunastri transplanted at urban, rural and industrial sites in Central Italy. J Atmos Chem 49:83-94

Cristofolini F, Giordani P, Gottardini E, Modenesi P (2008) The response of epiphytic lichens to air pollution and subsets of ecological predictors: a case study from the Italian Prealps. Environ Pollut 151:308-317

Das TM, Guha N, Majumdar S, Samim KA, Roy S, Das G, Das AK (1986) Studies on plant responses to air pollution: occurrence of lichens in relation to traffic load of Calcutta city. Indian Biol 18:26-29

Dzubaj A, Bačkor M, Tomko J, Peli E, Tuba Z (2008) Tolerance of the lichen Xanthoria parietina (L.) Th. Fr. to metal stress. Ecotoxicol Environ Safety 70:319-326

Ellis C, Coppins B (2010) Partitioning the role of climate, pollution and old-growth woodland in the composition and richness of lichen epiphytes in Scotland. Lichenologist 42:601-614

Garty J (1993) Lichens as biomonitors for heavy metal pollution. In: Markert B (ed) Plants as biomonitors. VCH, Weinheim, pp 193-264

Garty J (2001) Biomonitoring atmospheric heavy metals with lichens: theory and application. Crit Rev Plant Sc 20:309-371

Godinho RM, Verburg TG, Freitas MC, Wolterbeek HT (2009) Accumulation of trace elements in the peripheral and central parts of two species of epiphytic lichens transplanted to a polluted site in Portugal. Environ Pollut 157:102-109 
Hauck M (2011) Site factors controlling epiphytic lichen abundance in northern coniferous forests. Flora 206:81-90

Kar S, Nath B, Samal AC, Santra SC (2006) Arsenic in urban particulates-a case study in Kolkata metropolitan area. Curr Sci 90:158-160

Kar S, Maity JP, Samal AC, Santra SC (2010) Metallic components of traffic induced urban aerosol. Environ Monit Assess 168: $561-574$

Kar S, Maity JP, Samal AC, Santra SC, Jean JS, Bundschuh J (2013) Deposition and uptake of metals in urban canopy: atmospheric arsenic sequestration. J Hazard Mat (http://dx.doi.org/10.1016/ j.jhazmat.2012.12.048)

Karar K, Gupta AK, Kumar A, Biswas AK (2006) Characterization and identification of the sources of $\mathrm{Cr}, \mathrm{Zn}, \mathrm{Pb}, \mathrm{Cd}, \mathrm{Ni}, \mathrm{Mn}$ and $\mathrm{Fe}$ in PM10 particulates at the two sites of Kolkata. India Environ Monit Assess 120:347-360

Koz B, Celik N, Cevik U (2010) Biomonitoring of heavy metals by epiphytic lichens species in Black Sea region of Turkey. Ecolog Indicat 10:762-765

Kumar E, Bonalberti L, Piccoli F, Garasto G (1991) Lichen as monitors of air pollution. Grana 30:48-50

Loppi S, Nelli L, Ancora S, Bargagli R (1997) Accumulation of trace elements in the peripherial and central parts of a foliose thallus. Bryologist 100:251-253

Loppi S, Frati L, Paoli L, Bigagli V, Rossetti C, Bruscoli C, Corsini A (2004) Biodiversity of epiphytic lichens and heavy metal contents of Flavoparmelia caperata thalli as indicators of temporal variations of air pollution in the town of Montecatini Terme (central Italy). Sci Total Environ 326:113-122

Majumdar S, Ram SS, Jana NK, Santra S, Chakraborty A, Sudarshan M (2009) Accumulation of minor and trace elements in lichens in and around Kolkata, India: an application of X-ray fluorescence technique to air pollution monitoring. X-Ray Spectrom 38:469-473

Majumder S, Mishra D, Ram SS, Jana NK, Santra SC, Sudarshan M, Chakraborty A (2012) Physiological and chemical response of the lichen, Flavoparmelia caperata (L.) Hale, to the urban environment of Kolkata, India. Environ Sci Pollut Res. doi: 10.1007/s11356-012-1224-2

Minganti V, Capelli R, Drava G, De Pellegrini R, Brunialti G, Giordani P, Modenesi P (2003) Biomonitoring of trace metals by different species of lichens (Parmelia) in north-west Italy. J Atmosph Chem 45:219-229

Paoli L, Pisani T, Guttova A, Sardella G, Loppi S (2011) Physiological and chemical response of lichens transplanted in and around an industrial area of south Italy: relationship with the lichen diversity. Ecotoxicol Environ Safety 74:650-657

Phillips EA (1959) Methods of vegetation study. Holt, Rinehart and Winston Inc, New York

Rizzio E, Bergamaschi MG, Valcuvia MG, Profumo A, Gallorini M (2001) Trace element determination in lichens and in the airborne particulate matter for the evaluation of the atmospheric pollution in a region of northern Italy. Environ Int 26:543-549

Russellflegal A, Gallon C, Hibdon S, Kuspa Z, Laporte A (2010) Declinings but persistents atmospheric contamination in central California from the resuspension of historic leaded gasoline emissions as recorded in the lace lichen (Ramalina menziesii Taylor) from 1892 to 2006. Environ Sci Technol 44:5613-5618

Scheidegger C, Werth S (2009) Conservation strategies for lichens: insights from population biology. Fungal Biol Rev 23:55-66

Simonetti A, Gariepy C, Carignan J (2003) Tracing sources atmospheric pollution in western Canada using the $\mathrm{Pb}$ isotopic composition and heavy metal abundance of epiphytic lichens. Atmosph Environ 37:2853-2865

Uijily ME, Kumaraguru AK (2004) Accumulation of heavy metals in some species of lichens in south Tamilnadu, India. J Environ Sci Eng 46:186-193

Upreti DK (1996) Studies in Indian ethnolichenology—an overview. In: Jain SK (ed) Ethnobiology in human welfare. Deep Publications, New Delhi, pp 413-414

Upreti DK, Nayaka S, Bajpai A (2005) Do lichens still grow in Kolkata city? Curr Sc 88:338-339 